Vol. 24, No. 3, Juli 2021, hlm. 466-475

p-ISSN: 1410-9344; e-ISSN: 2549-5631

WARTA LPM

homepage: http://journals.ums.ac.id/index.php/warta

\title{
Home Teaching Era Pandemi Covid-19 pada Siswa SD sebagai Upaya Mengatasi Problematika Pembelajaran Daring
}

\author{
Anisatun Nuroniyah, Khuriyah \\ Pascasarjana IAIN Surakarta \\ Email: anisa.umykanza@gmail.com
}

\section{Article Info}

Submitted: 1 April 2021

Revised: 17 April 2021

Accepted: 8 May 2021

Published: 20 July 2021

Keywords: Home teaching, Pandemic Covid-19, and online problems
Kata kunci: Home teaching, Pandemi Covid-19, dan Problematika daring

\section{Abstract}

The covid-19 pandemic has not yet ended. Since its appearance in March 2020 in Indonesia, various sectors have been affected. The world of education is no exception. The government recommends that learning be carried out online so that the virus does not spread widely. But online learning creates all kinds of problems. For this reason, a breakthrough is needed to overcome online problems so that learning remains meaningful and is of interest to students. One solution to overcoming this problem is with home teaching activities, which is limited face-to-face learning following the provisions of health protocols. This method is carried out by means of the teacher visiting the homes of students of SD Djama'atul Ichwan in turns according to the group and the home teaching schedule which includes the implementation of teaching and learning activities from start to finish with a duration of 120 minutes. This activity was held from March 15 to April 8. This activity aims to make parents, students and teachers aware that home teaching is the right learning strategy, especially in the midst of the Covid-19 pandemic era. The conclusion from the home teaching activity is that online problems can be minimized with a limited face-to-face model during the implementation of home teaching. Through this model the real results obtained by students is the occurrence of a direct learning process between student-teacher, which psychologically will have a major influence on student learning outcomes because students can learn in a happy state of meeting their friends. In addition, the interactions that occur between students and teachers and students are able to maintain the social relations needed in order to get the best results in the teaching and learning process at SD Djama'atul Ichwan Surakarta.
Abstrak
Pandemi Covid-19 belum juga selesai. Sejak kemunculannya pada bulan Maret 2020 di Indonesia berbagai sektor ikut terdampak. Tak terkecuali dunia pendidikan. Pemerintah menganjurkan agar pembelajaran 
dilaksanakan secara daring agar virus tidak menyebar luas. Namun pembelajaran daring menimbulkan berbagai macam problematika. Untuk itu diperlukan terobosan mengatasi problematika pembelajaran daring agar pembelajaran tetap bermakna dan diminati siswa. Salah satu solusi mengatasi permasalahan itu adalah dengan kegiatan home teaching, yaitu pembelajaran tatap muka langsung terbatas mengikuti ketentuan protokol kesehatan. Metode ini dilakukan dengan cara guru mendatangi rumah-rumah siswa SD Djama'atul Ichwan secara bergilir sesuai kelompok dan jadwal home teaching meliputi pelaksanaan KBM dari awal hingga akhir dengan durasi waktu 120 menit. Kegiatan ini dilaksanakan mulai tanggal 15 Maret sampai 8 April. Kegiatan ini bertujuan agar orang tua, siswa, dan guru memiliki kesadaran bahwa home teaching merupakan strategi pembelajaran yang tepat terutama di lakukan di tengah era pandemi Covid-19. Simpulan dari kegiatan home teaching adalah problematika pembelajaran daring dapat diminimalkan dengan model tatap muka terbatas selama pelaksanaan home teaching. Melalui model ini hasil nyata yang diperoleh siswa adalah terjadinya proses pembelajaran langsung antara siswa-guru, yang secara psikologis akan berpengaruh besar pada hasil belajar siswa karena siswa dapat memperoleh pelajaran dalam kondisi suka cita bertemu teman-temannya. Selain itu interaksi yang terjadi antar siswa maupun guru dengan siswa mampu menjaga relasi sosial yang dibutuhkan dalam rangka memperoleh hasil terbaik dalam proses belajar mengajar di Sekolah SD Djama'atul Ichwan Surakarta.

\section{PENDAHULUAN}

Sejak ditemukan kasus Corona Virus Disease-2019 (Covid-19) pertama kali pada Maret 2020 di Indonesia, hampir seluruh sendi kehidupan sosial terkena dampaknya, tak terkecuali sektor pendidikan. Berbagai upaya telah dilakukan oleh pemerintah dengan mengeluarkan berbagai kebijakan agak seluruh aktivitas sosial-ekonomi masyarakat tetap bisa dilakukan secara terbatas. Kebijakan pemerintah menerapkan Pembatasan Sosial Berskala Besar (PSBB), penerapan new normal kepada masyarakat dengan mematuhi protokol kesehatan, seperti memakai masker, mencuci tangan dengan sabun dan air mengalir atau menggunakan hand sanitizer dan menjaga jarak, hingga Pemberlakuan Pembatasan Kegiatan Masyarakat (PPKM) tidak lain sebagai langkah antisipatif pemerintah dalam mencegah laju penyebaran virus Covid-19. Upaya ini setidaknya mampu mengurangi aktivitas masyarakat yang bersifat masal hingga bisa menekan terjadinya kerumunan massa yang sangat rentan menimbulkan cluster baru penyebaran virus. Upaya lain sebagai ikhtiar menciptakan hard immunity adalah program vaksinasi yang telah berlangsung sejak Januari 2021 dan akan berlanjut hingga menjangkau seluruh warga masyarakat.

Terkait dengan aktivitas pendidikan, meski saat ini telah berlangsung program vaksinasi, pembelajaran tatap muka, khususnya di sektor pendidikan dasar belum bisa diterapkan mengingat program vaksinasi belum menyentuh seluruh guru yang menjadi garda terdepan pelaksanaan pembelajaran di sekolah. Pelaksanaan pembelajaran tatap muka secara terbatas baru dimungkinkan penerapannya pada tahun pelajaran 20212022 setelah seluruh guru telah menjalani vaksinanasi yang direncanakan selesai pada bulan Juni mendatang. Dengan demikian, tanpa disadari pelaksanaan pembelajaran dalam jaringan (daring) telah berjalan lebih dari satu tahun yang pengaruhnya amat besar bagi dunia pendidikan, khususnya perubahan perilaku anak yang dipaksa harus bersentuhan dengan teknologi tanpa bekal cukup mengontrol 
penggunaan gadget bila tanpa pendampingan dari orang tua secara maksimal. Persoalan ini menjadi pekerjaan rumah tersendiri yang harus segera dicari jalan keluarnya agar tidak terjadi lost generation, atau generasi yang hilang akibat tidak adanya aktivitas pendidikan secara riil dan normal sebagaimana pembelajaran luar jaringan (luring). Solusi tepat mengatasi pembelajaran daring yang lebih berisiko bagi siswa usia tertentu harus dicarikan metode yang memungkinkan guru dan siswa bisa bertatap muka namun tetap aman dari kemungkinan terjadi penularan virus Covid-19.

Menurut Pujiasih (2020, p. 42) guru sebagai kunci utama keberhasilan untuk menghasilkan generasi emas Indonesia tahun 2045 yang bermutu dan berkualitas. Guru dituntut memiliki skill mampu menciptakan pebelajaran yang bermanfaat serta bermakna. Meski dalam kondisi pandemi Covid-19 pembelajaran harus tetap berlangsung. Guru harus mensiasatinya dengan menerapkan strategi yang tepat sehingga pembelajaran dapat berjalan sesuai ekspektasi. Lebih lanjut Pujiasih (2020, p. 44) menjelaskan pembelajaran bisa dilakukan secara online dengan menggunakan aplikasi Zoom, Jitzi, Google Class Meet, Webex, membuat video penjelasan singkat yang bisa dibagikan dengan WhatsApp, Youtube, dan rekaman video yang media ini bisa digunakan secara berulang-ulang. Senada dengan pendapat Asmuni (2020, p. 282) menyatakan ketika daring guru dan peserta didik melakukan pembelajaran bersama, waktu yang sama, dengan menggunakan berbagai aplikasi, seperti Whatsapp, Telegram, Zoom Meeting, Google Meet, Google Classroom, Quiepper School, ruang guru, dan aplikasi lainnya. Hal tersebut tak terlepas dari kemampuan IT guru.

Berdasarkan pengamatan di SD Djama'atul Ichwan, pada kenyataannya tidak semua guru, terutama guru yang sudah lanjut usia mengalami kesulitan dalam mengoperasikan aplikasiaplikasi yang berhubungan dengan pembelajaran daring, yang memungkinkan terhubung langsung dengan internet. Keterbatasan-keterbatasan ini secara tak langsung menghambat proses pembelajaran. Karena itu perlu dicari pilihan model pembelajaran yang lebih akomodatif bagi guru-guru tertentu yang mengalami permasalahan dengan teknologi. Terlebih guru dengan kategori tersebut lebih menyukai pembelajaran tatap muka langsung seperti lazim dilakukannya di kelas konvensional. Pada kenyataannya sistem konvensional belum sepenuhnya bisa digantikan dengan cara modern melalui berbagai aplikasi canggih sekalipun, sehingga tetap harus diupayakan cara solutif menghadapi problem belajar mengajar selain model dalam jaringan.

Penerapan model pembelajaran dalam jaringan bukan tanpa hambatan. Problem pembelajaran daring bagi siswa ternyata menimbulkan banyak persoalan baru. Berdasarkan pengamatan di SD Djama'atul Ichwan Surakarta siswa yang tak biasa dengan penggunaan teknologi maupun yang sudah familiar sama-sama menghadapi kendala. Bagi yang sudah terbiasa menggunakan belum tentu punya kemampuan mengoperasikannya tanpa pendampingan orang tua. Bagi yang tak memiliki perangkat yang dibutuhkan karena kondisi sosial ekonomi orang tuanya bisa menimbulkan persoalan lebih rumit dan kompleks yang menjadi beban tersendiri bagi orangtua dan problem bagi terhambatnya pelaksanaan pembelajaran. Bila selama ini siswa biasa berinteraksi secara langsung dalam proses belajar-mengajar, dalam daring mereka tak bisa lagi merasakan suasana belajar secara interaktif sebagaimana di kelas.

Sekolah dengan model pembelajaran daring yang berlangsung cukup lama berakibat siswa menjadi jenuh karena harus terus berada di dalam rumah dan tidak punya akses untuk bisa bertatap muka secara langsung dengan teman sebaya maupun bapak-ibu guru mereka. Dampak yang paling serius dari kondisi tersebut, karena siswa berada di rumah terlalu lama, pelan-pelan akan kehilangan jiwa sosial (Purwanto et al., 2020). Hasil penelitian Oktawirawan (2020, p. 542) menjelaskan bahwa pembelajaran daring menimbulkan kecemasan siswa. Pemicu kecemasan diantaranya kurang memahami materi, deadline tugas, internet tidak stabil, kesulitan mengerjakan tugas, kesulitan membeli kuota internet, kendala teknis, terlambat mengikuti kelas, dan tidak siap menghadapi jenjang selanjutnya. Kecemasan yang timbul bila tak segera teratasi akan berakibat lebih buruk bagi perkembangan psikologi anak yang 
bermuara pada perubahan perilaku dan masalah sosial yang ditimbulkannya.

Sedangkan bagi orang tua pembelajaran daring juga menimbulkan persoalan. Menurut Purwanto, dkk., (2020, p. 6) mengemukakan bahwa terjadi pembengkakkan biaya untuk membeli kuota internet. Padahal situasi pandemi Covid-19 orang tua sebagian terdampak ekonominya. Bagi orang tua yang sibuk bekerja dua-duanya tentu tidak bisa maksimal mendampingi anaknya belajar secara daring. Problem ini tentu harus bisa dicarikan solusi yang bisa mengakomodir kepentingan semua pihak, baik guru, siswa, dan orang tua sehingga ditemukan titik temu mengatasi persoalan yang dihadapi siswa dan orang tua.

Untuk mencari formula yang tepat menghadapi persoalan tersebut, perlu menginventarisasi problematika yang ada. Secara umum sesuai hasil penelitian Yantoro, dkk., (2021, p. 11) menjelaskan bahwa dalam daring terdapat beberapa kendala diantaranya masalah jaringan yang terkadang tidak stabil, listrik yang tidak bisa dipastikan nyala terus mengakibatkan jaringan tidak stabil dan mempengaruhi ketersediaan baterai, belum semua orang tua siswa memiliki HP android, guru tidak semua mempunyai skill dalam mengoperasikan aplikasi-aplikasi daring hingga kemampuan orang tua untuk memberi pendampingan belajar bagi putra-putrinya secara merata sehingga menjadi kendala tersendiri.

Dari beberapa problematika di atas maka perlu tindak lanjut sebagai upaya mengatasi permasalahan yang ada. Model pembelajaran home teaching menjadi salah satu terobosan yang tepat dan bisa menjadi alternatif. Home teaching sebenarnya hampir sama dengan home visit. Meskipun kedua konsep ini relatif sama tapi model home visit lebih terkesan sekadar kunjungan tanpa ada proses pembelajaran. Kunjungan umumnnya hanya menginspeksi kegiatan belajar siswa di rumah. Berbeda halnya dengan home teaching. Teaching sendiri memiliki arti mengajar, di mana idealnya durasi mengajar sesuai standar waktu yang dibutuhkan seperti pembelajaran normal, tidak sekadar berupa kunjungan. Jadi home teaching layaknya pembelajaran tatap muka seperti di kelas tetapi dilakukan di rumah dengan berbagai penyesuaian, terutama terkait dengan pemenuhan protokol kesehatan yang menjadi pijakan penting agar pembelajaran layaknya di kelas tetap bisa berlangsung secara aman dan berhasil guna. Hal-hal teknis, seperti penerapan zonasi tempat tinggal juga menjadi pertimbangan dalam penerapan model seperti ini demi keberlangsungan model home teaching sesuai harapan.

Pilihan pembelajaran tatap muka dengan konsep home teaching memiliki banyak kelebihan antara lain: 1. Penerapan disiplin formal pada pembelajaran tatap muka dapat memberikan sisi positif pada siswa yaitu disiplin mentalnya juga terbentuk; 2. Reinforcement atau penguatan pada pembelajaran dapat secepatnya diberikan; 3. Penilaian selama proses pembelajaran mudah diberikan; dan 4. Sebagai wadah belajar interaksi dengan peserta didik. Selain itu pembelajaran tatap muka memudahkan sosialisasi antara guru dan siswa. Pendidik dapat mengamati secara langsung proses KBM berlangsung (Khasanah et al., 2020, p. 42). Abdullah (2019, p. 143) menjelaskan bahwa home visit mampu meningkatkan kedisiplinan siswa, mampu memotivasi siswa, dan menciptakan interaksi yang baik antara siswa dan wali kelas.

Dengan terobosan baru pembelajaran tatap muka, orang tua, siswa, dan guru dapat merasakan manfaat home teaching sebagai inovasi baru strategi pembelajaran era pandemi Covid-19 yang mampu mengatasi problematika pembelajaran dalam jaringan. Model home teaching ini dalam pelaksanaannya mampu membangkitkan antusiasme baru siswa dalam belajar, gairah baru dan semangat orang tua saat mengantarkan anaknya home teaching ke lokasi tujuan. Kebahagian dan keceriaan juga mewarnai raut muka para siswa yang bisa kembali bertemu dengan teman-teman dan guru mereka. Sementara bagi guru akan kembali termotivasi untuk meningkatkan kemampuan mengajar agar siswa semakin tertarik mengikuti pembelajaran model home teaching.

\section{METODE}

Kegiatan ini menggunakan pendekatan fenomenology, yaitu studi atas fenomena yang terjadi berdasarkan pengalaman. Dengan 
demikian hal yang diperlukan dalam kegiatan ini adalah mengumpulkan informasi melalui interview, pengumpulan dokumen dan observasi lapangan langsung agar mendapatkan gambaran utuh dari objek kegiatan tersebut. Melalui interview atau wawancara pada sumber informasi, data primer yang dibutuhkan bisa langsung diperoleh. Selanjutnya dilakukan observasi lapangan untuk mendapatkan gambaran riil pelaksanaan kegiatan Langkah berikutnya yaitu mengumpulkan data dan mendokumentasikan seluruh hasil kegiatan yang dilaksanakan. Seluruh data yang telah diperoleh kemudian dianalisis dan dideskripsikan. Karena tidak semua dokumen yang diperoleh harus disajikan, maka diperlukan meringkas atau mereduksi hasil yang telah dideskripsikan untuk memperoleh hasil simpulan terbaik.

Dengan memilih objek kegiatan di SD Djama'atul Ichwan Surakarta, penulis menjadi instrument dan subjek dari kegiatan itu sendiri. Waktu pelaksanaan kegiatan dilakukan dalam rentang 25 Hari, mulai tanggal 15 Maret 2021 sampai 8 April 2021. Sumber informasi primer menjadi rujukan utama yang dikumpulkan dari para pemangku kebijakan kegiatan home teaching, seperti kepala sekolah, guru, dan warga sekolah yang terlibat dalam pelaksanaannya.

Gambaran mengenai pelaksanaan kegiatan home teaching, sebagaimana yang diperoleh di lapangan sebagai berikut; Pelaksanaan home teaching dilaksanakan setelah kegiatan Penilaian Tengah Semester (PTS) semester 2. Jadwal pelaksanaannya empat hari dalam seminggu mulai hari Senin sampai Kamis. Mengenai lokasi pelaksanaan home teaching ditetapkan sesuai kesepakatan dengan model bergilir agar setiap rumah siswa bisa mendapat kesempatan dijadikan tempat kegiatan home teaching. Dengan durasi sekitar 60-120 menit waktu efektif cukup menjadi solusi bagi problem pembelajaran daring. Kegiatan ini juga lebih nyaman karena siswa datang tidak menggunakan seragam sekolah tapi pakaian bebas dengan memenuhi norma kepantasan dan kesopanan.

Metode pelaksanakan kegiatan home teaching ditunjukkan pada gambar 1.

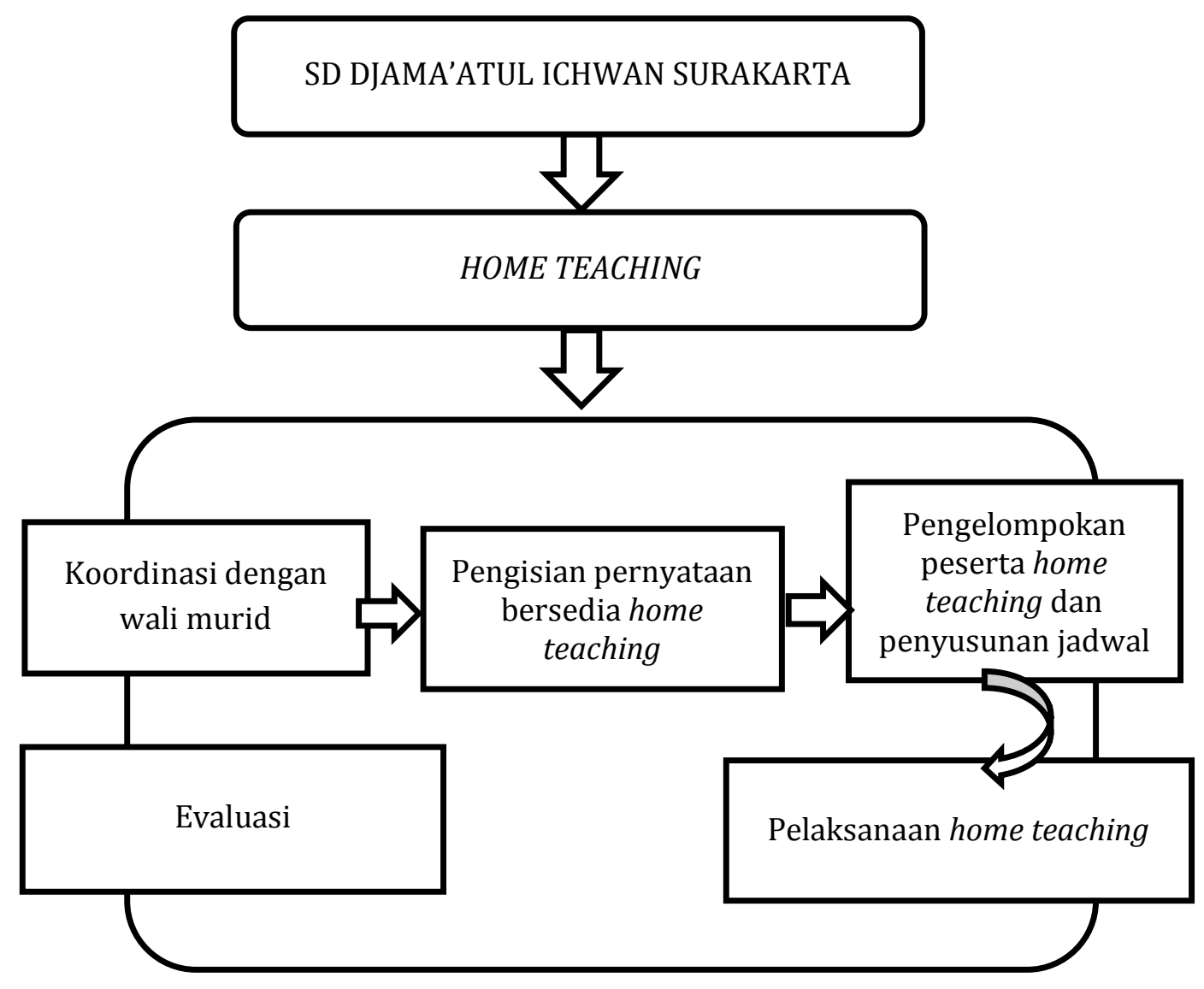

Gambar 1. Metode Pelaksanaan Home Teaching 
Sebagai langkah awal kegiatan home teaching adalah koordinasi dengan wali murid. Mereka diundang ke sekolah untuk diberi penjelasan mengenai manfaat kegiatan home teaching di aula sekolah. Protokol kesehatan tetap diperhatikan. Dimulai dari pengecekan suhu tubuh dengan thermogun oleh security di depan pintu masuk sekolah. Anjuran cuci tangan sebelum masuk juga diberlakukan dilengkapi wastafel dan sabun cair serta pengering tangan yang terletak samping pintu masuk sekolah. Beberapa wastafel lain juga disiapkan di beberapa titik di lingkungan sekolah. Tak hanya itu, beberapa botol hand sanitizer disediakan sekolah sebagai bentuk pencegahan merebaknya virus Covid-19. Semua yang terlibat menggunakan masker demikian juga jarak duduk diatur sedemikian rupa.

Tahap berikutnya pengisian pernyataan ketersediaan mengikuti home teaching. Ikut bersedia maupun tidak bersedia mengikuti home teaching merupakan hak mutlak orang tua. Tidak ada intervensi dari manapun. Bagi yang tidak mengikuti tidak akan berpengaruh terhadap perolehan nilai akhir rapor.

Selanjutnya pernyataan yang sudah diisi dikumpulkan dan didata untuk dibagi menjadi beberapa kelompok kecil. Pembagian kelompok memperhatikan aspek zonasi. Rumah yang saling berdekatan dijadikan satu kelompok dan masing-masing kelompok dipilih ketua kelompok. Pembagian kelompok ini tetap mempertimbangkan fleksibilitas dengan memberi opsi perubahan yang diperlukan jika wali murid menghendaki kelompok dengan pertimbangan tertentu yang bisa diterima.

Setelah kelompok selesai terbentuk, selanjutnya adalah penyusunan jadwal home teaching. Tentunya mempertimbangkan aspek keadilan semua kelompok dapat porsi yang sama. Baik segi kuantitas maupun kualitas home teaching. Hasil pembagian kelompok dan penyusunan jadwal dishare melalui grup WhatsApp kelas tanpa harus orang tua atau siswa datang ke sekolah.

Tahap berikutnya pelaksanaan home teaching di rumah siswa secara bergantian sesuai jadwal. Ketuntuan yang harus ditaati antara lain semua siswa harus berpakaian sopan dan rapi, mematuhi protokol kesehatan. Ketentuan ini hanya berlaku bagi siswa yang benarbenar dalam kondisi prima kesehatannya dan mendapat izin orang tua. Bagi siswa yang kondisi kesehatannya tidak prima tidak diwajibkan mengikuti home teaching dan harus istirahat di rumah. Sebagai pemenuhan hak belajar mereka yang tidak bisa mengikuti home teaching, materi pembelajaran akan dikirim melalui daring untuk tugas belajar di rumah.

Kegiatan yang terakhir adalah evaluasi melalui wawancara dengan siswa dan wali murid. Evaluasi diperlukan untuk menentukan tindak lanjut selanjutnya. Kekurangan dari kegiatan home teaching dicarikan solusi sehingga home teaching berikutnya sudah ada perbaikan. Sedangkan kelebihan home teaching terus dikembangkan.

\section{HASIL DAN PEMBAHASAN}

Kegiatan home teaching sudah dilaksanakan sejak tanggal 15 Maret 2021 semenjak selesai PTS semester 2 sampai tanggal 8 April 2021 sebelum libur awal ramadan. Menurut Makmun (2021, p. 24) home visit dalam satu hari hanya berjalan antara 25-30 menit tiap kelompoknya. Berbeda dengan home teaching yang berlangsung agak lama durasi 60 sampai 120 menit tergantung jadwalnya tiap kelompok. Dimulai pukul 08.0009.00. Pukul 09.00 istirahat kemuadian lanjut jam kedua pukul 09.30-10.30. Jumlah siswa maksimal tiap kelas adalah 28 siswa. Siswa yang tidak ikut tiap kelas rata-rata 2 sampai 3 orang. Perkelas terdiri dari 4 kelompok. Home teaching dilakukan dengan cara berkunjung ke rumah.

Pelaksanaan home teaching terdiri dari 3 tahap yaitu pembukaan, inti, dan penutup. Setelah itu istirahat menikmati kudapan yang disediakan secara iuran perkelompok atau tuan rumah yang menjamu tergantung kesepakatan kelompok masing-masing. Kegiatan rehat ini menjadi sarana penting mengembalikan keakraban dan kedekatan secara sosial diantara siswa setelah sekian lama tidak bertemu. Begitu istirahat selesai dilanjutkan mata pelajaran berikutnya.

Pertama, Pembukaan. Pada tahap ini layaknya pembelajaran tatap muka di sekolah. Dimulai dari doa sebelum pembelajaran, muroja'ah, atau membaca ulang (tadarus) 1 surat pendek. Orientasi dengan cara memberikan 
ilustrasi atau menunjukkan benda yang menarik yang berkaitan dengan materi. Apersepsi memberikan gambaran materi yang akan disampaikan. Motivasi akan pentingnya materi yang akan disampaikan sehingga siswa tertarik.

Kedua, Inti pembelajaran. Guru menyampaikan materi pembelajaran secara runtut, yaitu proses pembelajaran sesuai Kompetensi Dasar (KD). Metode pembelajarannya dilakukan secara interaktif, menyenangkan sekaligus menantang serta inspiratif dan memotivasi siswa untuk berpartisipasi aktif. Pada inti pembelajaran terjadi pendidikan penguatan karakter seperti religious, nasionalis, mandiri, gotong royong, dan integritas dapat terbentuk melalui kegiatan inti.

Ketiga, Penutup. Kegitan penutup meliputi arahan guru kepada siswa agar mampu membuat kesimpulan. Guru melakukan penilaian akhir. Penilaian proses dilakukan dari awal sampai akhir pembelajaran. Langkah selanjutnya guru memberikan arahan tindak lanjut pembelajaran dengan remedial bagi yang kurang mencapai Kriteria Ketuntasan Minimal (KKM) dan kegiatan pengayaan bagi siswa yang mencukupi KKM.

Berikut simpulan dari hasil kegiatan home teaching berpedoman pada hasil belajar yang diperoleh siswa selama mengikuti kegiatan home teaching. Intensitas pertemuan selama kegiatan berpengaruh besar pada hasil yang dicapai siswa serta memengaruhi hubungan yang lebih positif antara guru dengan orangtua walimurid.

Terlihat dalam tabel 1. Hasil dari observasi dan wawancara dengan siswa dan orang tua, perbedaan keadaan sebelum dan sesudah home teaching. Pada pembelajaran daring siswa sulit memahami materi. Setelah kegiatan, siswa lebih mudah memahami. Jika ada siswa yang belum paham, maka dapat ditanyakan secara langsung kepada gurunya. Hal ini sebagaimana terlihat pada gambar 2 .

Home teaching memberikan manfaat antara lain siswa semakin semangat mengikuti pelajaran. Yang tadinya jenuh bosan terlalu lama di rumah tidak bisa bercengkrama dengan teman-teman maka ketika home teaching senang sehingga motivasi belajar tumbuh.

Kegiatan home visit mempunyai peluang untuk mengetahui karakter siswa bagi guru (Mas'odi et al., 2020). Demikian juga home teaching juga berpeluang sama dengan home visit dapat mengetahui karakter siswa. Karakter siswa sangat penting agar siswa memiliki perilaku yang baik sesuai dengan ajaran agama. Pendidikan karakter menjadi tanggungjawab bersama guru dan orangtua.

Menurut Syibromilisi (2020) menjelaskan bahwa home visit merupakan inovasi yang dilakukan guru agar mempererat hubungan dengan wali murid. Tidak beda dengan home teaching. Kegiatan ini mampu membuka peluang perkuat jalinan ukhuwah antara guru dengan orangtua siswa. Terlihat pada gambar 4.

Home teaching membangkitkan semangat bagi guru dalam melaksanakan tugas sebagai pendidik. Selama daring tidak bisa berinteraksi langsung dengan siswa, ketika home teaching mampu bertatap muka dalam satu waktu dan tempat.

Tabel 1. Keadaan Sebelum dan Sesudah Pelaksanaan Kegiatan Home Teaching

\begin{tabular}{cll}
\hline No. & Keadaan sebelum kegiatan home teaching & \multicolumn{1}{c}{ Keadaan setelah kegiatan home teaching } \\
\hline 1 & Siswa sulit memahami materi daring & Siswa lebih mudah memahami materi \\
2 & Enggan kirim tugas & Lebih semangat menyelesaikan tugas \\
3 & Penilain tugas siswa tidak bisa langsung & Penilain tugas siswa bisa langsung \\
4 & Memerlukan biaya untuk koata & Tidak memerlukan biaya koata \\
5 & Jenuh bosan di rumah serta guru tidak & Senang bertemu dengan teman-teman dan guru \\
& bisa menilai aspek tingkah laku & bisa menilai tingkah laku dalam pembentukan \\
& & karakter \\
6 & Hubungan guru dengan wali murid biasa & Hubungan ukhuwah lebih erat \\
7 & Tergantung jaringan & Tidak tergantung jaringan \\
\hline
\end{tabular}




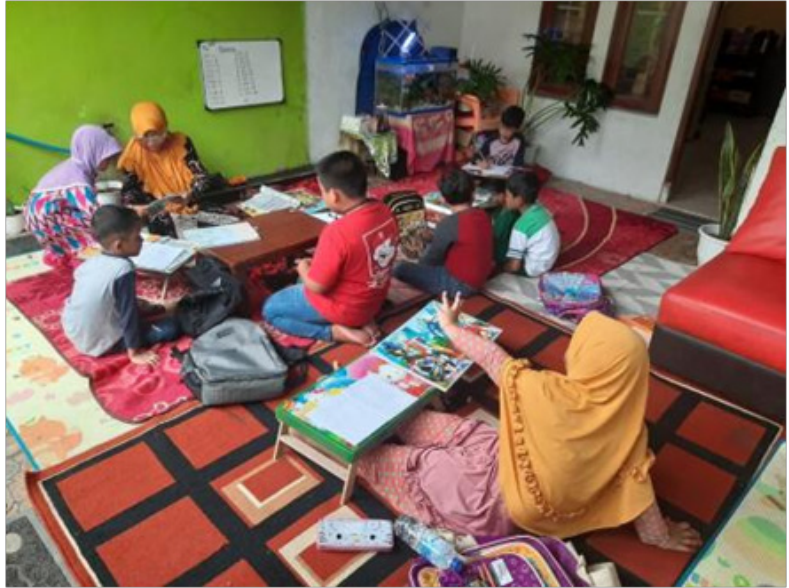

Gambar 2. Siswa Bertanya Materi yang Belum Dipahami. Guru Memberi Penjelasan Secara Langsung

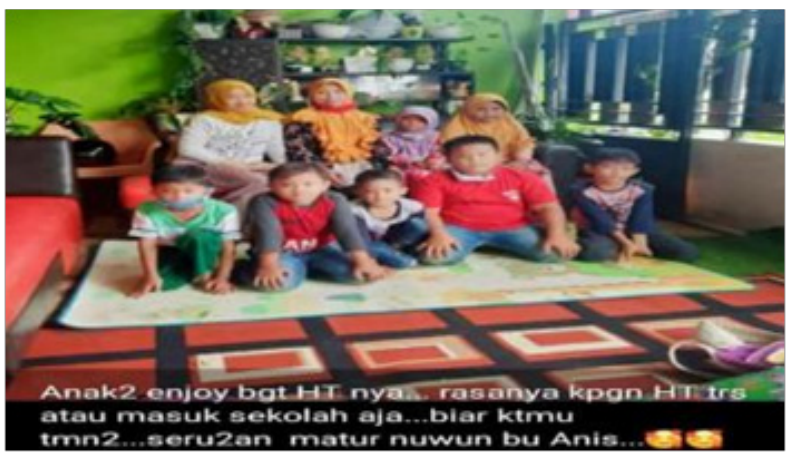

Gambar 4. Foto Bersama setelah Kegiatan Home Teaching yang Diunggah Oleh Salah Satu Wali Murid Menunjukkan Respon Positif dan Berpengaruh pada Relasi Guru-Wali Murid Menjadi Lebih Erat.

Pembelajaran tatap muka terbukti efektif dan memberi dampak positif bagi proses transfer ilmu sekaligus interaksi sosial diantara mereka yang selama pembelajaran daring tidak bisa terpenuhi secara maksimal.

\section{SIMPULAN}

Bentuk kegiatan pengabdian ini adalah home teaching. Dalam home teaching guru mengajar ke rumah-rumah siswa sesuai jadwal. Berbeda dengan home visit yang hanya berdurasi antara 25-30 menit sekali kunjungan, home teaching pada pengabdian ini durasi waktunya sampai 120 menit dalam sekali kunjungan pada setiap kelompoknya. Guru mengajar materi sama dengan ketika kondisi normal di sekolah. Durasi waktu tersebut cukup untuk proses kegiatan belajar mengajar.

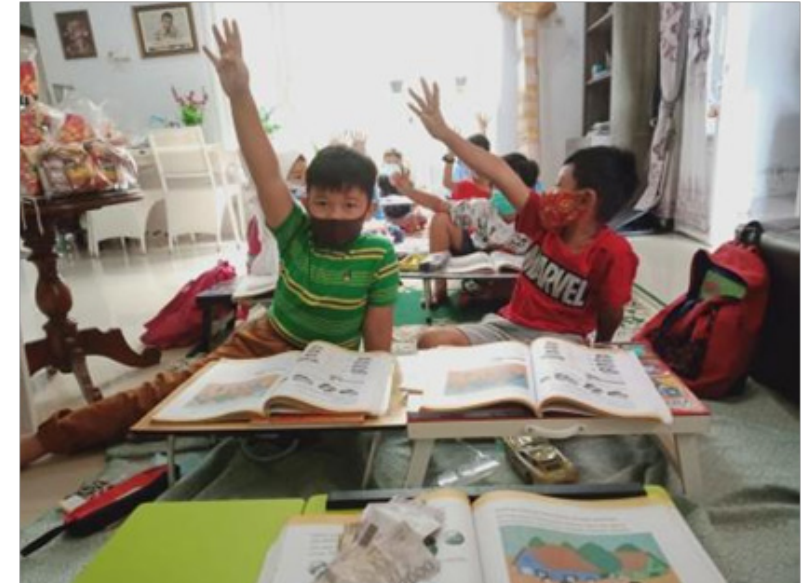

Gambar 3. Siswa Bersemangat Mengikuti Pembelajaran dengan Strategi Home Teaching.

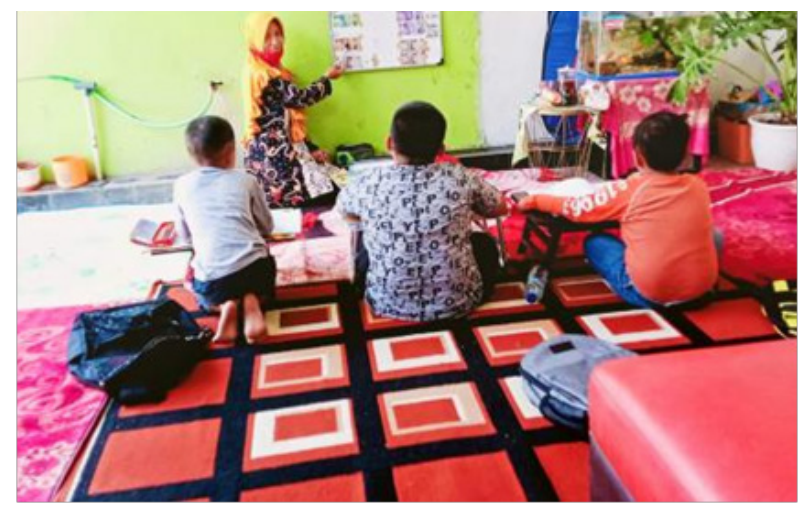

Gambar 5. Ibu Anis Melaksanakan Home Teaching dengan Bersemangat.

Kegiatan home teaching mampu meminimalisasi problematika pembelajaran daring. Dengan home teaching, baik guru, siswa, maupun orang tua riang gembira, tidak tergantung adanya jaringan sehingga tidak memerlukan biaya kuota internet, siswa dengan semangat menyelesaikan tugas yang diberikan guru sehingga punya nilai yang berbeda jauh ketika daring. Materi pembelajaran dapat disampaikan secara detail oleh guru secara langsung sehingga siswa lebih mudah memahami. Dengan home teaching pula membuka peluang guru pendidikan karakter siswa. Hasil dari kegiatan ini menunjukkan bahwa siswa terlihat antusias mengikuti pembelajaran tatap muka home teaching. Rata-rata perkelas semua siswa mengikuti kecuali 2 sampai 3 siswa. Hal ini menunjukkan bahwa home teaching sangat 
diminati. Hubungan antara guru dan orang tua semakin erat karena bisa bertemu langsung pula ketika menunggui atau antar jemput anaknya ke lokasi home teaching.

Berdasarkan hasil kegiatan pengabdian masyarakat berupa home teaching ini, kendala yang muncul antara lain respon masyarakat yang beragam terkait boleh tidaknya mengadakan kegiatan home teaching di musim pandemi, meski sudah memenuhi protokol kesehatan dalam pelaksanaannya. Saran untuk kegiatan selanjutnya adalah perlunya dukungan dari pihak pemerintah memberikan izin secara legal formal agar pelaksanaannnya bisa lebih maksimal dengan tetap memenuhi persyaratan dan ketentuan yang diwajibkan terutama dalam memenuhi protokol kesehatan bagi yang terlibat dalam kegiatan tersebut. Pemberian izin sangat penting agar dalam pelaksanaannya bisa terkontrol dan terukur serta tidak terkesan kucing-kucingan dengan pihak-pihak tertentu yang berwenang, seperti pihak gugus tugas penanggulangan Covid-19 ataupun masyarakat sekitar yang tidak berkenan dengan kegiatan tersebut karena dianggap beresiko menjadi cluster penularan virus dan lain sebagainya. Dengan demikian kegiatan yang telah mendapatkan apresiasi potitif dari semua warga sekolah, baik guru, murid maupun wali murid ini dapat memberi sumbangsih bagi problem pembelajaran dalam jaringan yang selama ini mengalami berbagai kendala, baik teknis maupun non teknis serta problem sosial yang ditimbulkannya.

\section{PERSANTUNAN}

Penulis menyampaikan ucapan terima kasih yang setulusnya kepada kepala sekolah SD Djama'atul Ichwan Surakarta, Ghufron Ghozali, S.E.,S.Pd., M.M. yang telah memberikan izin kegiatan home teaching. Kepada orang tua wali murid yang mendukung penuh kegiatan pembelajaran tatap muka berupa home teaching. Dengan terbuka rumah-rumah mereka menyambut dengan ramah sebagai lokasi kegiatan pembelajaran, yang akan memberi makna mendalam bagi penghuni rumah karena tempat tinggalnya digunakan sebagai kegiatan belajar mengajar. Terima kasih dan apresiasi sebesar-besarnya atas jamuan baik yang diberikan kepada siswa maupun guru yang tentunya tidak sedikit bila dinominalkan. Di tengan kondisi pandemi yang berdampak pada kemampuan secara ekonomi tak menyurutkan penghormatan yang telah diberikan menunjukkan ikatan sosial dan ukhuwah yang telah terbentuk diantara keluarga besar warga sekolah SD Djama'atul Ichwan. Terima kasih juga untuk siswa-siswa SD Djama'atul Ichwan yang dengan suka cita dan riang gembira menyambut hangat kegiatan pengabdian ini sehingga menambah ghiroh semangat energi positif bagi penulis dalam menjalankan tugas selama home teaching. Kepada masyarakat sekitar rumah orang tua yang telah mendukung kegiatan home teaching. Kepada semua pihak yang tidak bisa disebutkan satu persatu yang telah mensupport penuh kegiatan pengabdian masyarakat ini sehingga bisa berjalan dengan lancar.

\section{REFERENSI}

Abdullah, E. (2019). Home Visit oleh Guru atau Wali Kelas dan Motivasi Belajar Siswa. Jurnal Kajian Pembelajaran Dan Keilmuan, 3(2), 142-149. https://jurnal.untan.ac.id/index.php/jurnalkpk/ article/view/41208

Asmuni, A. (2020). Problematika Pembelajaran Daring di Masa Pandemi Covid-19 dan Solusi Pemecahannya. Jurnal Paedagogy, 7(4), 281. https://doi.org/10.33394/jp.v7i4.2941

Khasanah, D. R. A. U., Pramudibyanto, H., \& Widuroyekti, B. (2020). Pendidikan dalam Masa Pandemi Covid-19. Jurnal Sinestesia, 10(1), 41-48. https://sinestesia.pustaka.my.id/journal/article/ view/44

Makmun, S. (2021). Kombinasi Pembelajaran Media Daring dengan Strategi Home Visit pada Masa Pandemi Covid-19 pada Sekolah Dasar Negeri 1 Batu Layar. 6(1), 20-25. 
Mas'odi, M., Syaifuddin, M., \& Amirullah, A. (2020). Pengembangan Karakter Siswa melalui Kegiatan Home Visit (Studi Kasus Tingkat Sekolah Dasar di Kabupaten Sumenep). Jurnal Pemikiran Dan Pengembangan Sekolah Dasar (JP2SD), 8(2), 107-117. https://doi.org/10.22219/jp2sd. v8i2.11734

Oktawirawan, D. H. (2020). Faktor Pemicu Kecemasan Siswa dalam Melakukan Pembelajaran Daring di Masa Pandemi Covid-19. Jurnal Ilmiah Universitas Batanghari Jambi, 20(2), 541. https://doi. org/10.33087/jiubj.v20i2.932

Pujiasih, E. (2020). Membangun Generasi Emas dengan Variasi Pembelajaran Online di Masa Pandemi Covid-19. Jurnal Karya Ilmiah Guru, 5(1), 42-48.

Purwanto, A., Pramono, R., Asbari, M., Santoso, P. B., Wijayanti, L. M., Choi, C. H., \& Putri, R. S. (2020). Studi Eksploratif Dampak Pandemi Covid-19 terhadap Proses Pembelajaran Online di Sekolah Dasar. EduPsyCouns: Journal of Education, Psychology and Counseling, 2(1), 1-12. https:// ummaspul.e-journal.id/Edupsycouns/article/view/397

Syibromilisi, S. (2020). Strategi Belajar SIEQ melalui Home Visit di Masa Pandemi Covid-19 (Corona Virus Deases). Tsaqafatuna, 4(2).

Yantoro, Y., Hariandi, A., Mawahdah, Z., \& Muspawi, M. (2021). Inovasi guru dalam Pembelajaran di Era Pandemi Covid-19. JPPI (Jurnal Penelitian Pendidikan Indonesia), 7(1), 8-15. 